\title{
Correction to: Downexpression of HSD17B6 correlates with clinical prognosis and tumor immune infiltrates in hepatocellular carcinoma
}

Lei $\mathrm{Lv}^{1 \dagger}$, Yujia Zhao ${ }^{2 \dagger}$, Qinqin Wei ${ }^{2}$, Ye Zhao ${ }^{2}$ and Qiyi Yi ${ }^{*}$

\section{Correction to Cancer Cell Int (2020) 20:210 http:// doi.org/10.1186/s12935-020-01298-5}

Following publication of the original article [1], we were notified of a few changes in the author affiliations. The correct affiliations for the authors are listed below:

Lei $\mathrm{Lv}^{1,+}$, Yujia Zhao ${ }^{2,+}$, Qinqin $\mathrm{Wei}^{2}$, Ye Zhao ${ }^{2}$, Qiyi Yi ${ }^{2, *}$

${ }^{1}$ Anhui Provincial Cancer Hospital, West Branch of the First Affiliated Hospital of USTC, Division of Life Sciences and Medicine, University of Science and Technology of China, Hefei 230031, Anhui, People's Republic of China.

${ }^{2}$ Teaching and Research Section of Nuclear Medicine, Anhui Medical University, 81 Meishan Road, Hefei 230032, Anhui, People's Republic of China.

\begin{abstract}
Author details
${ }^{1}$ Anhui Provincial Cancer Hospital, West Branch of the First Affiliated Hospital of USTC, Division of Life Sciences and Medicine, University of Science and Technology of China, Hefei 230031, Anhui, People's Republic of China.

${ }^{2}$ Teaching and Research Section of Nuclear Medicine, Anhui Medical University, 81 Meishan Road, Hefei 230032, Anhui, People's Republic of China.
\end{abstract}

Published online: 02 October 2020

\section{Reference}

1. Lv L, Zhao Y, Wei Q, Zhao Y, Yi Q. Downexpression of HSD17B6 correlates with clinical prognosis and tumor immune infiltrates in hepatocellular carcinoma. Cancer Cell Int. 2020;20:210. https://doi.org/10.1186/s1293 5-020-01298-5

\section{Publisher's Note}

Springer Nature remains neutral with regard to jurisdictional claims in published maps and institutional affiliations.

Full list of author information is available at the end of the article

(c) The Author(s) 2020. This article is licensed under a Creative Commons Attribution 4.0 International License, which permits use, sharing, adaptation, distribution and reproduction in any medium or format, as long as you give appropriate credit to the original author(s) and the source, provide a link to the Creative Commons licence, and indicate if changes were made. The images or other third party material in this article are included in the article's Creative Commons licence, unless indicated otherwise in a credit line to the material. If material is not included in the article's Creative Commons licence and your intended use is not permitted by statutory regulation or exceeds the permitted use, you will need to obtain permission directly from the copyright holder. To view a copy of this licence, visit http://creativecommons.org/licenses/by/4.0/. The Creative Commons Public Domain Dedication waiver (http://creativecommons.org/publicdomain/zero/1.0/) applies to the data made available in this article, unless otherwise stated in a credit line to the data. 